\title{
Persepsi Guru Tentang Pembelajaran Sains Anak Usia 5-6 Tahun di Gugus II Melati Kecamatan Simpang Tiga Pekanbaru
}

\author{
Rahmah \\ Universiti Kebangsaan Malaysia \\ rabmab_ukm@yahoo.com
}

\begin{abstract}
The research was conducted to determine the teacher's perception of the science learning of 5-6 year olds in cluster II Melati Simpang Tiga pekanbaru. This research was carried out through descriptive qualitative methods and using techniques of collecting observation and interview data. This study uses qualitative analysis techniques. Based on the results of the study, the results obtained that learning science can help teachers to know what children want and what they expect. The results of the data obtained were teacher perceptions of science learning in Gugu II Melati, Simpang Tiga Pekanbaru District, in terms of the study aspects of plants or plants, which were good enough and able to apply. Teacher's perception of science learning in Gugug II Melati, Simpang Tiga Pekanbaru Subdistrict, in terms of aspects of the study of animals or animals is quite good, but still has difficulties in holding or bringing into the classroom and the lack of zoos to be visited. Teacher perceptions of science learning in Melati Clusters, Pekanbaru City Simpang Tiga District, from the aspect of study of animal and plant relations, are quite good and easy to explain to children. difficult to explain and involves something very complex.
\end{abstract}

\section{Keywords ; Perception and Learning Science}

\begin{abstract}
Abstrak
Penelitian yang dilakukan bertujuan untuk mengetahui persepsi guru tentang pembelajaran sains anak usia 5-6 tahun di gugus II Melati kec. Simpang Tiga Kota pekanbaru. Penelitian ini dilakukan melalui metode deskriptif kualitatif, dan menggunakan teknik pengumpul data observasi dan wawancara. Penelitian ini menggunakan teknik analisis kualitatif. Berdasarkan hasil penelitian, maka diperoleh hasil bahwa pembelajaran sains mampu membatu guru untuk mengetahui apa yang anak inginkan dan menjelajah segala apa yang mereka harapkan Hasil penelitian data yang diperoleh adalah Persepsi guru TentangPembelajaran sains di Gugu II Melati Kecamatan Simpang Tiga Kota Pekanbaru ditinjau dari aspek study tanaman atau tumbuhan cukup baik dan mampu menerapkan. Persepsi guru Terhadap Pembelajaran sains di Gugug II Melati kec. Simpang Tiga Kota Pekanbaru ditinjau dari aspek study tentang hewan atau binatang cukup baik akan tetapi masih mengalami kesulitan dalam
\end{abstract}


mengadakan atau mendatangkan kedalam ruang kelas dan minimnya kebun binatang yang akan dikunjungi. Persepsi guru Terhadap Pembelajaran sains di Gugus Melati kec. Simpang Tiga Kota Pekanbaru ditinjau dari aspek study hubungan hewan dan tanaman cukup baik dan mudah menjelaskannya kepada anak Persepsi guru Terhadap Pembelajaran sains di Gugus II Melati kec. Simpang Tiga Pekanbaru ditinjau dari aspek hubungan aspek kehidupan masih dirasa sulit dijelaskan dan menyamngkut sesuatu yang sangat kompleks.

\section{Kata kunci ; Persepsi dan Pembelajaran Sains}

\section{PENDAHULUAN}

Pendidikan salah satu proses yang dapat memberikan pengalaman dan pengetahuan tersebut. Proses pendidikan yang berlangsung tersebut hendaknya dilaksanakan secara professional. Keberlangsungan pendidikan tidak terlepas dari peran guru, guru memiliki dominasi dalam pendidikan khususnya pendidikan anak usia dini. Selain itu guru harus memahami bagaimana memanfaatkan segenap potensi yang ada, seperti penggunaan media. Apabila guru tidak memahami media maka sulit dalam menggunakannya. Proses belajar mengajar yang dilakukan oleh guru disekolah keberhasilannya tidak terlepas dari berbagai komponen pendidikan yang lain. Dalam pembelajaran dikelas terutama proses belajar mengajar, guru sesuai kompetensi yang dimilikinya memiliki kemampuan pedagogic yang memadai.

Berdasarkan UU No 14 tahun 2005 tentang guru dan dosen dinyatakan beberapa kompetensi yang harus dimiliki oleh guru selain kemampuan akademik dengan standar sarjana. Akan tetapi kesarjaannya belum dapat dimungkinkan akan berprilaku professional. Pengetahuan setiap guru sangat variatif sehingga perlu adanya pengukuran pengetahun yang tidak sekedar nilai saat menguikuti jenjang diperguruan tinggi saja. Pengetahuan mereka akan terakumulasi saat mengadakan pembelajaran dikelas.

Setelah diperlakukannya Permen 58 tahun 2009 tentang standar pendidikan anak usia dini, proses pembelajaran pengembangan kognitif dan aspek lain menjadi peranan penting. Pembelajaran aktif dan kreatif sangat memungkinkan anak berkembang optimal. Pembelajaran yang sesuai dengan rasa ingin tahu anak yang tinggi, suka menjelajah dan memperhatikan sesuatu secara detail merupakan proses pembelajaran sains, walaupun masih sangat sederhana. Anak melalui proses bertanya sesuangguhnya ingin mencari banyak tahu tentang hal yang menarik di muka bumi.

Untuk pembelajaran sains mampu mengakomodir apa yang anak inginkan dan menjelajah segala apa yang mereka harapkan, akan tetapi semua tergantung pada pendidik untuk menyikapinya. Cara pandang guru terhadap sesuatu sangat berpengaruh pada sikap dan prilaku yang ditampilkan saat mengajar. Oleh sebab itu persepsi guru terhadap berbagai aspek pembelajaran di pendidikan anak usia dini bervariasi, dimulai dari yang positif mengembangkan pembelajaran sampai pada hanya sekedar memenuhi tugas masuk ke dalam kelas saja. Hal ini tidak terkecuali pada pembelajaran sains. 
Pembelajaran sains selama ini dipandang sebagai suatu pembelajaran yang menyulitkan dan memerlukan banyak bahan serta pengetahuan yang cukup luas.Apalagi pengetahuan tentang sains sangat dekat dengan Ilmu pengetahuan Alam (IPA).Guru PAUD lebih menginginkan pembelajaran yang tidak memerlukan banyak penalaran dan sesuai dengan kondisi anak yang masih belum mampu menalar lebih jauh. Pandangan lain dari beberapa guru bahwa pembelajaran sains dapat menghabiskan waktu belajar yang lain sehingga pembelajaran sain tidak dapat dilihat hasilnya, berbeda dengan fisik motorik.

Masih ada terdapat persepsi negative tentang pembelajaran sains dan belum merasa perlu, dikarenakan anak setelah masuk sekolah dasar akan mempelajari juga. Pengetahuan guru terhadap pembelajaran sains masih rendah sehingga kurang diminati dan anak tidak memperoleh banyak pengalaman tentang sains. Dan masih kurangnya kreativitas guru dalam menerapkan pembelajaran sains, sehingga media yang akan digunakan dirasakan sulit untuk diperoleh. Serta pola pikir guru masih memandang penting pembelajaran lainnya dibandingkan dengan pembelajaran sains itu sendiri.

\section{KAJIAN TEORETIS}

Winardi (2004:46) persepsi menjelaskan sebuah proses internal yang bermanfaat sebagai sebuah alat penyaring (filter) dan sebagai sebuah metode untuk mengorganisasi sitimuli (rangsangan), yang memungkinkan kita menghadapi lingkungan. Proses persepsi tersebut menyediakan mekanisme melalui stimuli diseleksi dan dikelompokkan dalam wujud yang berarti. Akibatnya adalah kita lebih dapat memahami gambaran total tentang lingkungan yang diwakili oleh stimuli tersebut.

Persepsi adalah kemampuan untuk membeda-bedakan, mengelompokkan, memfokuskan dan sebagainya itu, disebut kemampuan untuk mengorganisasikan pengamatan. Persepsi tiap individu terhadap suatu objek dapat saja berbeda, hal ini merupakan suatu hal yang wajar karena menyangkut karakteristik dan kemampuan individu pula. Hal ini sejalan dengan pendapat yang dikemukakan oleh Slameto (2003:102) mengenai prinsip-prinsip persepsi. Slameto (2003:102) beberapa prinsip dasar tentang persepsi yaitu:

a. Persepsi itu relatif bukannya absolut

b. Persepsi itu selektif

c. Persepsi itu mempunya tatanan

d. Persepsi dipengaruhi oleh harapan dan kesiapan (penerima rangsangan)

\section{Faktor yang Mempengaruhi Persepsi}

Menurut Slameto (2003:102) persepsi seseorang atau kelompok dapat jauh berbeda dengan persepsi orang atau kelompok lain sekalipun situasinya sama. Perbedaan persepsi ini dapat ditelusuri pada adanya perbedaan-perbedaan individual, perbedaan kepribadian, harapan, perbedaan dalam sikap atau perbedaan dalam motivasi. Hal senada juga dikemukakan oleh Sondang P. Siagian (2005:100) bahwa secara umum dapat dikatakan bahwa terdapat tiga faktor yang mempengaruhi 
persepsi seseorang: Diri orang yang bersangkutan sendiri, Sasaran persepsi dan Faktor situasi.

Bimo Walgito (2002:70) juga menambahkan karena persepsi merupakan aktivitas yang integrated dalam diri individu, maka apa yang ada dalam diri individu akan ikut aktif dalam persepsi. Berdasarkan hal tersebut, maka dalam persepsi dapat dikemukakan karena perasaan, kemampuan berfikir, pengalaman-pengalam individu tidak sama, maka dalam mempersepsi sesuatu stimulus, hasil persepsi mungkin akan berbeda antara individu satu dengan individu lain. Persepsi bersifat individual. Setiap individu memiliki perbedaan persepsi, hal ini di dapat disebabkan oleh hal-hal seperti perhatian, kebutuhan, sistem nilai, dan ciri kepribadian.

Arikunto dalam Nugraha (2008:19), menyatakan bahwa persepsi dipengaruhi faktor- faktor yaitu :

a. Ciri khas objek stimulus yang memberikan nilai bagi orang yang mempersiapkannya dan seberapa jauh objek tertentu dapat menyenangkan bagi seseorang.

b. Faktor- faktor pribadi termasuk di dalamnya ciri khas individu, seperti taraf kecerdasan, minat, emosional dan lain sebagainya.

c. Faktor pengaruh kelompok,artinya respon orang lain di lingkungannya dapat memberikan arah kesuatu tingkah laku.

d. Faktor perbedaan latar belakang tingkah laku kultural (kebiasaan).

\section{Pembelajaran Sains Anak Usia Dini}

Kata Sains berasal dari kata Latin scientia yang berarti " Saya tahu ".Sain dapat diartikan ilmu yang mempelajari sebab akibat dari kejadian yang terjadi di alam ini. Tetapi banyak kejadian yang tidak dapat atau belum dapat dijelaskan oleh sains.Kamus mendefenisikan natural science sebagai systematic and formulated knowledge dealing with material phenomena and based mainly on observation and induction, yaitu ilmu sistematis dan dirumuskan yang berhubungan dengan gejala-gejala kebendaan, dan didasarkan atas pengamatan dan induksi.Meskipun kegiatan dalam sains hampir selalu berhubungan dengan eksperimen namun konsep sains adalah hasil tanggapan pikiran manusia atas gejala yang terjadi di alam ini. Sains merupakan suatu "badan pengetahuan tentang benda-benda si alam yang diperoleh dengan cara tertentu.Sains mulai dengan fakta dan berakhir dengan fakta.Teori merupakan suatu bagian yang penting yang mana teori dibuat menjelaskan hukum dan meramalkan sesuatu yang baru ( Padmonodewo, $2000 ; 90$ )

\section{Pentingnya Pembelajaran Sains}

Pembelajaran sains merupakan suatu keharusan karena dapat dijadikan sebagai standar menentukan tingkat ketercapaian keberhasilan dari suatu program pembelajaran yang dikembangkan dan dilaksanakan. Suatu tujuan yang dianggap menjadi standard dan memiliki karakteristik yang ideal apabila tujuan yang dirumuskan memiliki tingkat ketepatan (validity), kebermaknaan (meaningfulness), fungsionjal dan relevansi yang tinggi dengan kebutuhan serta karakteristik sasaran.

Tujuan pendidikan sains sejalan dengan tujuan kurikulum yang ada di sekolah yaitu, mengembangkan anak secara utuh baik pikirannya,hatinya maupun jasmaninya 
atau mengembangkan intelektual, emosional dan fisik jasmani atau aspek kognitif,afektif dan psikomotorik anak (Senjaya; 2008 ; 87). Tujuan yang mendasar dari pendidikan sains adalah untuk mengembangkan individu agar melek terhadap ruang lingkup sains serta mampu menggunakan aspek fudamentalnya dalam memecahkan masalah yang dihadapinya. Lima tujuan dalam pengembangan program sains menurut TIM Penyusun UNP (2008), yaitu;

a. Membawa siswa untuk menentukan nilai dan kemampuan dalam menduga permasalahan, pendekatan terhadap maslah serta merealisasikan aktivitas pemecahannya.

b. Mengembangjkan kepercayaan diri siswa akan kemampuan memecahkan masalah dengan menggunakan pikiranya sendiri.

c. Membantu siswa agar memiliki dorongan diri untuk menggunakan kemampuannya dalam menghadapi berbagai mata pelajaran.

d. Mengembangkan cara berfikir ekonomis melalui pengembangan belajar yang mendorong mencari relevansi dan struktur dari apa yang dipelajarnya.

e. Mengembangkan kejujuran intelektual yakni kesadaran menggunakan peralatan dan bahan-bahan dari pengetahuan untuk menilai dan menguji suatu pemecahan masalah, gagasan dan dugaan-dugaannya ia juga harus jujur dalam menghargai berbagai ilmu pengetahuan yang diperolehnya.

Menurut Ali Nugraha (2008 ; 95) bahwa Ruang lingkup sains dilihat dari isi bahan kajian meliputujagat raya(ilmu tentang bumi)mempresentasikan tentang pengetahuan-pengetahuan yang benar melalui alam semesta, meliputi astronomi, geologi, meteorology.Topik-topik umum pembelajaran pada anak usia dini,meliputi: 1) pengetahuan tentang binatang, matahari dan planet 2) kajian tentang tanah, batuan dan pegunungan, 3) kajian tentang cuaca.

\section{Pendekatan Guru dalam Perkembangan Sains.}

Model pengembangan program pembelajaran atau kurikulum yang dapat dijadikan pedoman dalm pengembangan program pembelajaran sains pada anak usia sini. Tiga pendekatan pengembangan kurikulum sains pada jenjang pendidikan anak usia dini, menurut Ali Nugraha $(2005,89)$ sebagai berikut;

a. Pendekatan yang bersifat situasional,yaitu pembahasan tentang sains akan dielaborasi secara luasdan mendalam jika dalam pembelajaran muncul ' fenomena' yang terkait dengan tuntutan pembahasan konsep dan pengalaman sains pada sasaran belajar.

b. Pendekatan yang bersifat terpisah atau tersendiri,yaitu program pengembangan pembelajaran sains dikemas secara khusus dan tersendiri

c. Pendekatan yang bersifat merger atau terintegrasi,yaitu pendekatan yang dikembangkan dengan cara digabungkan secara formaldan sistematis dengan bidang pengembangan atau disiplin ilmu lainnya.

Menurut Senjaya (2008 98) Strategi atau cara-cara dipilih dengan pertimbangan dapat menyajikan dan memberikan aktivitas sains secara memadai serta terintegrasi pada anak, baik secara kelompok maupun individu.Dalam penerapan berbagai strategi tersebut dapat silih berganti dan saling mengisi sehingga kegiatannya menjadi lebih bermakna.Pelaksanaan kegiatan sains dilaksanakan di 
sudut area. Keterampilan Proses Sains dan yang dilatihakan ( Nugraha, 2008 ;93) yaitu;
a. Mengamati
b. Menggolongkan/Mengelompokan
c. Menafsirkan/Meramalkan
d. Meramalkan/Memprediksi
e. Menerapkan
f. Merencanakan penelitian
g. Mengkomunikasikan
h. Organisasi Kelas Untuk Pembelajaran Sains Pada Anak Usia Dini

Prinsipnya adalah guru harus dapat membagi material yang dibutuhkan untuk anak secara adil, memadai dan memungkinkan kegiatan pembelajaran sains berlagsung secara optimal.Kemampuan mengenal karakteristik dari setiap material sains, akan memudahkan dalam menyeleksi, memproduksi sekaligus

Terkait dengan penyediaan arena untuk aktivitas sains, terdapat beberapa hal lain yang harus diperhatikan;

a. Aktivitas sains yang disediakan guru harus memungkinkan terjadinya interaksi antar group.

b. Meski guru memberikan kesempatan berkomunikasi antar kelompok anak yang sedang mempelajari sains, tetapi guru harus dapat mengkondisikan kelas agar jangan sampai terjadi kontak antar group yang sifatnya tidak perlu.

c. Karena pada umumnya kelas yang ada cendrung dalam format tradisional,tugas guru yang utama dalam pengelolaan kelas adalah menemukan cara bagaimana memanfaatkan kelas tradisional menjadi kelas yang optimal dalam pembelajaran sains yang dilakukan dan dibawah bimbingannya.

d. Sarana penunjang kelas, seperti bangku,meja dan membelair hendaklah dikembangkan peralatan yang bersifat fleksibel dan anak sendiri mampu menata serta memindah-mindahkan.

Agar aktivitas berlangsung secara optimal dan dinamis,adalah kemampuan guru dalam memberikan penjelasan atu petunjuk kerja yang benar, jelas dan dimengerti oleh setiap anak sebagai peserta belajar sains seabab $n$ ih pembelajaran sains akan muncul ketika anak tidak memahami harapan guru dan tuntutan tujuan dari aktivitas yang akan dan harus dilaksanakannya.

\section{METODOLOGI PENELITIAN}

Berdasarkan perumusan masalah di atas, maka penelitian bertujuan untuk mengetahui Persepsi guru tentang pembelajaran sains anak usia 5-6 tahun di Gugus II Melati Kecamatan Simpang Tiga Kota Pekanbaru. Tempat penelitian ini dilaksanakan di Gugus II Melati Kecamatan Simpang Kota Pekanbaru dan dilaksanakan setelah seminar proposal. Penelitian ini dilakukan pada bulan januariMaret 2018.

\section{Metode Penelitian}

Jenis penelitian ini adalah bersifat deskriptif dengan pendekatan kualitatif yang bertujuan memberikan gambaran secara sistematis tentang keadaan yang 
sedang berlangsung pada objek penelitian yaitu tentang Persepsi guru terhadap pembelajaran sains (Sukardi, 2008;157). Obyek penelitian pada penelitian ini adalah objek yang mempunyai kualitas dan karakteristik tertentu yang ditetapkan oleh peneliti. Berdasarkan kondisi tersebut tersebut maka obyek dalam penelitian ini adalah seluruh Guru yang ada di Gugus II Melati Kecamatan Simpang Tiga Kota Pekanbaru berjumlah 30 orang.

\section{Teknik Pengumpulan Data}

Penelitian ini mengunakan teknik pengumpulan data yang meliputi berbagai cara yakni melalui pengamatan (observasi), wawancara dan studi dokumentasi. Ketiga teknik pengumpulan data tersebut digunakan dengan harapan saling melengkapi sehingga dapat diperoleh data yang akurat kemudian diklafikasikan menurut jenisnya, yaitu data primer dan skunder. Data primer diperoleh melalui observasi dan wawancara sedangkan data sekunder diperoleh dari strudi dokumentasi.

\section{Teknik Analisis Data}

Analisis data adalah proses mengorganisasikan dan mengurutkan data ke dalam pola, kategori, dan satuan uraian dasar sehingga dapat ditemukan tema dan dapat dirumuskan hipotesa kerja. Analisis data merupakan proses mencari dan mengatur secara sistematis transkrip wawancara, catatan lapangan, dan bahan-bahan lain yang telah dihimpun untuk menambah pemahaman mengenai bahan-bahan itu dan melaporkan yang telah ditemukan kepada pihak lain. Dapat disimpulkan bahwa analisa data adalah pengorganisasian data, mengurutkan dan membentuknya ke dalam pola, katergori dan uraian dasar untuk pemberian makna dan pemahaman.

Tahap kedua adalah penyajian data yakni proses pemberian sejumlah informasi yang telah disusun memungkinkan peneliti menarik kesimpulan dan mengambil tindakan. Dan selanjutnya tahap ketiga menarik kesimpulan. Adapun teknik analisis data yang dapat digunkan dalam penelitian ini adalah sebagai berikut; (Jhon Creswell, 2011;245)

a. Peneliti mengumpulkan data untuk dianalisis (Mengorganisasi data)

b. Mengkode deskripsi dan tema tentang fenomena umum (Mendeskripsikan Data)

\section{HASIL PENELITIAN DAN PEMBAHASAN}

Dalam penelitian ini akan dibahas tentang Persepsi guru tentang pembelajaran sains di Gugus II Melati Kecamatan Simpang Kota Pekanbaru . Untuk mengetahui lebih mendalam tentang Persepsi guru tentang pembelajaran sains di Gugus II Melati Kecamatan Simpang Tiga Kota Pekanbaru terlebih dahulu peneliti kemukakan tentang profil guru di Gugus II Melati Kecamatan Simpang Kota Pekanbaru .

Dalam penelitian ini, guru yang dijadikan objek penelitian adalah sebagian guru di Gugus II Melati Kecamatan Simpang Kota Pekanbaru, sedangkan yang menjadi informan penelitian adalah 6 orang guru. Dalam penelitian tentang pembelajaran sains ini, guru dijadikan informan . 


\section{Hasil Penelitian Tentang Pembelajaran Sains di Gugus II Melati Kecamatan Simpang Kota Pekanbaru}

Berdasarkan hasil observasi dan wawancara yang dilakukan terhadap responden dalam penelitian yang berjudul persepsi guru tentang pembelajaran sains di Gugus II Melati Kecamatan Simpang Tiga sesuai dengan indikator yang disajikan sebagai berikut;

\section{a. Analisis Persepsi guru Tentang Pembelajaran sains di Gugus II Melati Kecamatan Simpang Tiga Kota Pekanbaru}

Untuk mengetahui Persepsi guru tentang pembelajaran sains di Gugus II Melati Kecamatan Simpang Tiga Kota Pekanbaru.peneliti melakukan wawancara. ditujukan terhadap guru yang menjadi objek penelitian, sedangkan wawancara dilakukan terhadap guru yang ada di gugus Melati. Adapun indikator untuk variabel pembelajaran sains adalah sebagai berikut:

a. studi tentang tumbuhan

b. studi tentang binatang atau hewan

c. studi tentang hubungan tumbuhan dengan hewan

d. studi tentang hubungan antara aspek-aspek kehidupan dengan lingkungannya

Dari keempat indikator tersebut jelas terlihat bahwa yang menjadi analisis dari persepsi pembelajaran sains adalah bagian pembelajaran yang tidak terpisahkan dari proses yang dilaksanakan oleh guru itu sendiri, sehingga penjelasan akan berkaitan dengan kondisi saat ini dan yang akan datang sesuai sudut pandang masing-masing respondenj yaitu guru. Adapun uraian tiap indikator dapat peneliti uraikan sebagai berikut;

\section{a. Persepsi Guru Tentang Studi Tumbuhan}

Pada saat melaksanakan wawancara untuk pertama kalinya, yaitu pada hari Senin tanggal 5 Februari pada saat jam istirahat, peneliti menanyakan kepada guru. Pada indikator aspek tumbuhan terdapat sub indikator sebagai berikut; a). bagianbagian tumbuhan (akar, batang, daun ,bunga dan buah). b). ukuran tumbuhan yang sedang tumbuh, c). proses atau asal tumbuhan (biji/tunas). Study tentang tumbuhan berdasarkan kondisi yanga da disekitar bukanlah hal yang luar biasa, akan tetapi bagi anak sangat luar biasa apa bila dikemas dengan cara yang menyenangkan dan menantang. Tumbuhan menjadi menarik bila disajikan dalam bentuk eksperimen. Dan proses tersebut juga dapat dilakukan dengan menggunakan media audio visual atau film tertentu.

Tabel 1. Deskripsi umum Persepsi guru Tentang Pembelajaran Sains pada indikator study tumbuhan

\begin{tabular}{|c|c|c|}
\hline No & Sub indikator & Hasil observasi dan wawancara \\
\hline 1. & Aspek bagian-bagian tumbuhan & $\begin{array}{l}\text { Secara umum persepsi guru terhadap study } \\
\text { tentang tumbuhan dalam pembelajaran sains } \\
\text { pada aspek atau sub indikator bagian-bagian } \\
\text { tumbuhan cukup baik mereka beranggapan } \\
\text { bahwa mudah diterapkan akan tetapi masih } \\
\text { sangat jarang, dalam pembelajaran guru masih }\end{array}$ \\
\hline
\end{tabular}




\begin{tabular}{|l|l|l|}
\hline & & $\begin{array}{l}\text { senang menjelaskan dari pada mengajak anak } \\
\text { kekebun, }\end{array}$ \\
\hline 2. & Aspek proses atau asal tumbuhan & $\begin{array}{l}\text { Pada aspek asal tumbuhan, baik dari biji, tunas } \\
\text { dan sebagainya , apalagi untuk penjelasan kepada } \\
\text { anak artinya pembelajaran sains yang diterapkan } \\
\text { dengan penjelasan tentang tumbuhan atau } \\
\text { tanaman mudah apabila dikombinasikan dengan } \\
\text { metode eksperimen yang biasa dilakukan dengan } \\
\text { menggunakan contoh tumbuhnya kacang ijo } \\
\text { menjadi kecamba.. }\end{array}$ \\
\hline 3. & $\begin{array}{l}\text { Aspek ukuran tumbuhan yang } \\
\text { sedang tumbuh }\end{array}$ & $\begin{array}{l}\text { Ukuran setiap tanaman tidak sama tergantung } \\
\text { kesuburan dan bibit dari tanaman itu sendiri, } \\
\text { maka guru lebih cenderung memberikan anak } \\
\text { kesempatan mengukur tanaman sesuai dengan } \\
\text { kondisi saat ini. Dan prediksi tumbuh disaat } \\
\text { mendatang. }\end{array}$ \\
\hline
\end{tabular}

Sumber: Data Olahan Penelitian, 2018

\section{Persepsi Guru Tentang Studi Hewan/Binatang}

Hasil penelitian terhadap persepsi guru gugus II Melati Pada indikator studi hewan/binatang terdapat sub indikator sebagai berikut; a). jenis atau kelompok hewan. b). cara berkembang biak hewan c).hidup atau tempat hewan berkembang biak. Persepsi guru tentang hewan atau binatang bervariasi apalagi dalam mengenalkan binatang tersebut kepada anak sehingga anak mudah memahami dan memperoleh pengalaman baru. Maka berdasarkan hasil penelitian diperoleh data sebagai berikut; (berdasarkan hasil observasi dan wawancara yang dilaksanakan terhadap 6 orang guru), yaitu;

Tabel 2. Deskripsi Persepsi guru TentangPembelajaran sains dari indikator studyu hewan atau binatang

\begin{tabular}{|l|l|l|}
\hline No. & Aspek/sub indikator & Hasil observasi dan wawancara \\
\hline 1. & jenis atau kelompok & $\begin{array}{l}\text { Secara umum persepsi guru terhadap study tentang hewan } \\
\text { hewan } \\
\text { menghadirkan hewan secara langsung, maka guru selalu } \\
\text { menggunakan gambar hewan atau miniature hewan }\end{array}$ \\
\hline 2. & $\begin{array}{l}\text { cara berkembang biak } \\
\text { hewan }\end{array}$ & $\begin{array}{l}\text { Sedangkan tempat seperti kebun binatang yang akan } \\
\text { dikunjungi sangat terbatas, contohnya yaitu anak ingin } \\
\text { melihat gajah dan harimau, maka guru beranggapan sulit } \\
\text { menerapkannya. Cara hewan berkembang biak dapat } \\
\text { dijelaskan guru dengan mudah. }\end{array}$ \\
\hline 3. & $\begin{array}{l}\text { hidup atau tempat hewan } \\
\text { berkembang biak. }\end{array}$ & $\begin{array}{l}\text { Setiap hewan atau binatang memiliki habibat masing- } \\
\text { masing, maka berdasarkan persepsi guru, bahwa hewan } \\
\text { dapat hidup dimana saja, akan tetapi tetap memiliki } \\
\text { tempat, seperti sangkar.. }\end{array}$ \\
\hline
\end{tabular}

Sumber: Data Olahan Penelitian, 2018

\section{Persepsi Guru Tentang Studi Hubungan Tumbuhan dengan Hewan}


Penelitian tentang persepsi guru terhadap pembelajaran sain berdasarkan indikator studi hubungan tumbuhan dengan hewan derdasarkan sub indikator atau aspek sebagai berikut; a) tumbuhan memerlukan hewan untuk hidup dan sebaliknya. Pada saat melaksanakan wawancara untuk indicator mengagumi, penelitian dilaksanakan mulai pada hari senen 5 februari 2018 pada saat jam istirahat, peneliti menanyakan kepada guru yaitu pertanyaan dan observasi sesuai dengan sub indikator tersebut diatas, maka diperoleh hasil sebagai berikut:

Tabel 3. Deskripsi Persepsi guru Tentang Pembelajaran sains pada indikator hubungan tumbuhan dengan hewan.

\begin{tabular}{|c|c|c|}
\hline No. & Aspek/sub indikator & Hasil observasi dan wawancara \\
\hline 1. & $\begin{array}{l}\text { tumbuhan } \\
\text { memerlukan } \\
\text { hewan untuk } \\
\text { hidup dan } \\
\text { sebaliknya }\end{array}$ & $\begin{array}{l}\text { Secara umum persepsi guru terhadap study tentang } \\
\text { simbiosis mutualisme atau saling menguntungkan, } \\
\text { sehingga didunia setiap tanaman dan makhluk lainnya } \\
\text { saling melengkapi, hewan memerlukan tumbuhan dan } \\
\text { tumbuhan juga membantu hewan }\end{array}$ \\
\hline 2. & $\begin{array}{l}\text { tumbuhan dan hewan } \\
\text { saling membantu } \\
\text { perkembang biakan }\end{array}$ & $\begin{array}{l}\text { Saling membantu untuk berkembang biak secara langsung } \\
\text { mungkin tidak, akan tetapi tumbuh kembang dan tidak } \\
\text { saling memiliki korelasi dan hubungan yang erat. }\end{array}$ \\
\hline
\end{tabular}

Sumber: Data Olahan Penelitian, 2018

\section{Persepsi Guru Tentang Studi Hubungan antara Berbagai Aspek Kehidupan}

Wawancara tentang indikator pembelajaran sains yang diteliti berdasarkan studi hubungan antara berbagai aspek kehidupan dengan rincian sub indikator sebagai berikut; a). hubungan saling menguntungkan (simbiolis mutualisme). b). terjadinya siklus hewan maupun tumbuhan dimuka bumi. Berdasarkan dua sub indikator tersebut diatas maka diperoleh data yang dilangsungkan pada hari Senin tanggal 7 Februari 2018 pada saat jam istirahat.

Tabel 4. Deskripsi Persepsi guru TentangPembelajaran sains di Gugus II Flamboyan Kecamatan Rumbai Pesisir Kota Pekanbaru (Kesimpulan Umum)

\begin{tabular}{|l|l|l|}
\hline No. & Pertanyaan & Jawaban \\
\hline 1. & $\begin{array}{l}\text { Bagaimana pendapat ibu } \\
\text { tentang study tumbuhan } \\
\text { dalam pembelajaran sains } \\
?\end{array}$ & $\begin{array}{l}\text { Secara umum persepsi guru terhadap study tentang } \\
\text { tumbuhan dalam pembelajaran sains cukup baik mereka } \\
\text { beranggapan bahwa mudah diterapkan akan tetapi masih } \\
\text { sangat jarang apalagi untuk penjelasan kepada anak artinya } \\
\text { pembelajaran sains yang diterapkan dengan penjelasan } \\
\text { tentang tumbuhan atau tanaman mudah apabila } \\
\text { dikombinasikan dengan metode eksperimen yang biasa } \\
\text { dilakukan dengan menggunakan contoh tumbuhnya } \\
\text { kacang ijo menjadi kecamba. }\end{array}$ \\
\hline 2. & $\begin{array}{l}\text { Bagaimana pendapat ibu } \\
\text { tentang study hewan atau } \\
\text { binatang dalam } \\
\text { pembelajaran sains? }\end{array}$ & $\begin{array}{l}\text { Kemudian para guru beranggapan bahwa hanya beberapa } \\
\text { jenis hewan yang dapat dijadikan pembelajaran sains } \\
\text { karena sulitnya menghadirkan hewan yang sebesnarnya } \\
\text { kecuali menggunakan miniature hewan dan gambar, }\end{array}$ \\
\hline
\end{tabular}




\begin{tabular}{|l|l|l|}
\hline & & $\begin{array}{l}\text { sedangkan tempat seperti kebun binatang yang akan } \\
\text { dikunjungi sangat terbatas, contohnya yaitu anak ingin } \\
\text { melihat gajah dan harimau, maka guru beranggapan sulit } \\
\text { menerapkannya. }\end{array}$ \\
\hline 3. & $\begin{array}{l}\text { Bagaimana pendapat ibu } \\
\text { tentang studi hubungan } \\
\text { tanaman /tumbuhan } \\
\text { dengan hewan? }\end{array}$ & $\begin{array}{l}\text { Dalam usaha mengetahui hubungan tumbuhan dengan } \\
\text { hewan sangat mudah sehingga guru lebih memberikan } \\
\text { apresiasi dan ilustri terhadap sapid an kerbau atau kambing } \\
\text { makan rumput. Sehingga terlihat bahwa terdapat } \\
\text { hubungan hewan dengan tumbuhan yang saling } \\
\text { menguntungkan dan memiliki keterkaitan erat, persepsi } \\
\text { guru terhadap pembelajaran sains mengganggap sangat } \\
\text { sedikit yang dapat dilakukan dan mengajak orang tua } \\
\text { sendiri ke kebun binatang karena rasa penasaran. }\end{array}$ \\
\hline 4. & $\begin{array}{l}\text { Bagaimana pendapat ibu } \\
\text { terhadap study tentang } \\
\text { hubungan dalam aspek } \\
\text { kehidupan? }\end{array}$ & $\begin{array}{l}\text { Persepsi guru terhadap pembelajaran sains anak ditinjau } \\
\text { dari aspek tentang hubungan dalam aspek kehidupan } \\
\text { diketahui bahwa rata-rata guru memiliki keinginan } \\
\text { tersebut. Persepsi terhadap hubungan dalam aspek } \\
\text { kehidupan dalam pembelajaran sains memiliki kemampuan } \\
\text { tingkat tinggi untuk menjelaskan kepada anak sehingga } \\
\text { guru harus memiliki pengetahuan dan pengalaman yang } \\
\text { lebiuh. Hal yang diperlukan adalah kemampuan membaca } \\
\text { dan menggali buku IPA }\end{array}$ \\
\hline
\end{tabular}

Sumber: Data Olahan Penelitian, 2018

\section{Pembahasan}

Dari hasil penelitian dapat dikemukakan bahwa secara umum guru yang memiliki pengetahuan tentang pembelajaran sains ditunjukkan dengan indikator. Demikian halnya dengan pembelajaran sains pada anak. Berdasarkan hasil wawancara yang dilakukan terhadap guru yang ada di gugus II Melati ditemukan bahwa guru masih memiliki persepsi yang berbeda dan sebagian besar mereka memahami pembelajaran sains hanya sebatas pemahaman konsep seperti pembelajaran ilmu pengetahuan alam (IPA), sedangkan penerapan untuk anak usia dini (PAUD) khususnya TK masih kurang. Hal ini dikarenakan kemampuan yang guru miliki dalam menyediakan sarana pendukung masih kurang. Persepsi guru tentang pembelajaran sains pada aspek study tentang tanaman atau tumbuhan adalah guru beranggapan bahwa study tanaman lebih mudah diterapkan dan sering digunakan dalam pembelajaran di TK melalui gambar-gambar dalam buku atau praktek langsung Artinya, guru yang memiliki pengetahuan yang cukup untuk menerapkan dan mempraktekkan pembelajaran sains aspek tentang study tanaman atau tumbuhan.

Persepsi guru terhadap pembelajaran sains mengganggap sangat sedikit yang mampu diterapkan karena banyak alasan. Anak baru bisa memperhatikan dengan baik apabila ada obyek langsung atau melalui gambar, selain itu ada juga yang berusaha melihat miniature bendanya. Dan Persepsi guru tentang pembelajaran sains anak ditinjau dari aspek hubungan berbagai kehidupan tanaman dengan hewan dan lingkungan masih cukup karena penjelasan lebih rinci masih belum dikuasai dan guru belum memiliki kemampuan lebih. Akan tetapi Persepsi guru tentang 
pembelajaran sains secara keseluruhan di Gugus II Melati Kecamatam Simpang Tiga Kota Pekanbaru ditinjau dari seluruh aspek masih kategori baik.

Kondisi tersebut diatas dapat dicapai dengan baik apabila guru mampu menerapkan secara baik sesuai dengan tahapan, berikut menurut Sri Ningsih (makalah seminar, 2010). Bidang pembelajaran sains merupakan suatu keharusan karena dapat dijadikan sebagai standar menentukan tingkat ketercapaian keberhasilan dari suatu program pembelajaran yang dikembangkan dan dilaksanakan.Suatu tujuan yang dianggap menjadi standard an memiliki karakteristik yang ideal apabila tujuan yang dirumuskan memiliki tingkat ketepatan (validity), kebermaknaan (meaningfulness), fungsional dan relevansi yang tinggi dengan kebutuhan serta karakteristik sasaran.

Tujuan pendidikan sains sejalan dengan tujuan kurikulum yang ada di sekolah yaitu, mengembangkan anak secara utuh baik pikirannya,hatinya maupun jasmaninya atau mengembangkan intelektual,emosional dan fisik jasmani atau aspek kognitif, afektif dan psikomotorik anak.Tujuan yang mendasar dari pendidikan sains untuk mengembangkan individu agar melek terhadap ruang lingkup sait mampu menggunakan aspek fudamentalnya dalam memecahkan masalan yang dihadapinya.

\section{PENUTUP}

Dari hasil analisa yang telah peneliti kemukakan dapat diambil kesimpulan berikut ini. Persepsi guru Tentang Pembelajaran sains di Gugus II Melati Kecamatan Simpang Tiga Pekanbaru ditinjau dari aspek study tanaman atau tumbuhan cukup baik dan mampu menerapkan. Persepsi guru Terhadap Pembelajaran sains di Gugus II Melati Kecamatan Simpang Tiga Kota Pekanbaru ditinjau dari aspek study tentang hewan atau binatang cukup baik akan tetapi masih mengalami kesulitan dalam mengadakan atau mendatangkan kedalam ruang kelas dan minimnya kebun binatang yang akan dikunjungi. Dan Persepsi guru Terhadap Pembelajaran sains di Gugus II Melati Kecamatan Simpang Tiga Kota Pekanbaru ditinjau dari aspek study hubungan hewan dan tanaman cukup baik dan mudah menjelaskannya kepada anak Persepsi guru Terhadap Pembelajaran sains di Gugus II Melati Kecamatan Simpang Tiga Kota Pekanbaru ditinjau dari aspek hubungan aspek kehidupan masih dirasa sulit dijelaskan dan menyangkut sesuatu yang sangat kompleks.

Berdasarkan hasil penelitian yang telah dilaksanakan, peneliti mengajukan beberapa saran, yaitu: guru senantiasa memberikan peluang kepada anak menggali banyak hal dialam dengan pembelajaran sains. Selain itu bagi guru hendaknya lebih mengetahui dan belajar banyak tentang pembelajaran sains dan bagi guru agar secara rutin memberikan perhatian dengan bertanya atau atau referensi buku tentang alam dan bahan mengajar lainnya.

\section{DAFTAR PUSTAKA}

Anwar, 2009. Pendidikan Anak Usia Dini. Bandung:Alfabeta, Departemen Pendidikan Nasional. 
Bimo Walgito, 2002, Pengantar Psikologi Umum, Andi Offset,Yogyakarta.

Iqbal Hasan, 2008, Analisis Data Penelitian dengan Statistik, Bumi Aksara, Jakarta.

Jhon Creswell, 2011, Penelitian Kualitatif dalam Bidang Pendidikan, Pekanbaru, UMRI Press.

Nugraha, Ali. 2005. Pengembangan Pembelajaran Sains Anak Usia Dini. Jakarta:

Padmonodewo, Soemiarti.2000.Pendidikan Anak Pra Sekolah.Jakarta:Rineka Cipta.

Senjaya, Wina. 2008. Strategi Pembelajaran. Berorientasi Standar Proses Pendidikan. Jakarta: Kencana Prenada Media Group.

Sukardi, 2008, Metodologi Penelitian Pendidikan, Bumi Aksara, Jakarta.

Tim Docto Rabbit. 2005. Mengenal Sains. Jakarta: Erlangga For Kids.

Tim Penyusun Fakultas Negeri Padang. 2008. Bahan Ajar Belajar dan Pembelajaran. UNP.

Slamento , 2003, Belajar dan Faktor yang Mempengarubinya, Jakarta, Rineka Cipta.

Sondang P.Siagian, 2002, Pengantar Ilmu Manajemen, Jakarta.

Sri Ningsih, 2010, makalah seminar, Jakarta.

Winardi, 2004, Motivasi dan Pemotivasian dalam Manajemen, Jakarta, Raja grafindo persada. 